\title{
Ping-pong gaze and ocular nodding in bacterial meningitis
}

回舟

Supplemental data at Neurology.org
A 27-year-old man presented with fever, somnolence, seizure, and nuchal rigidity. CSF culture indicated Streptococcus pneumoniae, confirming the diagnosis of bacterial meningitis. Ping-pong gaze was observed initially, and then replaced by what we called ocular nodding after IV administration of diazepam (video at Neurology.org). The eyes went downward and returned to primary position slowly, smoothly, and periodically (with a cycle lasting 12-17 seconds and a pause between 2 cycles), resembling a nodding head. He became alert with free eye movement within 3 days of antibiotic treatment. Ping-pong gaze has been reported, ${ }^{1}$ but ocular nodding is a novel finding.

Yan Wang, MD, * Yong-Heng Huang, MD, * Shi-Lin Yang, MD

*These authors contributed equally to this work.

From the Department of Neurology (Y.W., S.-L.Y.), Shanghai General Hospital, Shanghai Jiao Tong University School of Medicine (originally Shanghai First People's Hospital); and Department of Ophthalmology (Y.-H.H.), Eye \& ENT Hospital, Fudan University, Shanghai, China.

Author contributions: Yan Wang: management and follow-up of the patient. Yong-Heng Huang: acquisition of information. Shi-Lin Yang: supervision and critical revision of manuscript.

Study funding: No targeted funding reported.

Disclosure: The authors report no disclosures relevant to the manuscript. Go to Neurology.org for full disclosures.

Correspondence to Dr. S.-L. Yang: yangshilin@gmail.com

1. Senelick RC. "Ping-pong” gaze: periodic alternating gaze deviation. Neurology 1976;26:532-535.

\section{Visit the Neurology ${ }^{\circledR}$ Resident \& Fellow Website}

Click on Residents \& Fellows tab at Neurology.org.

Now offering:

- Neurology ${ }^{\circledR}$ Resident \& Fellow Editorial team information

- "Search by subcategory" option

- E-pearl of the Week

- RSS Feeds

- Direct links to Continuum ${ }^{\circledR}$, Career Planning, and AAN Resident \& Fellow pages

- Recently published Resident \& Fellow articles

- Podcast descriptions

(1) Find Neurology ${ }^{\circledR}$ Residents \& Fellows Section on Facebook: http://tinyurl.com/o8ahsys

twitter Follow Neurology ${ }^{\circledR}$ on Twitter: http://twitter.com/GreenJournal 


\section{Neurology}

\section{Ping-pong gaze and ocular nodding in bacterial meningitis \\ Yan Wang, Yong-Heng Huang and Shi-Lin Yang \\ Neurology 2017;89;2021 \\ DOI 10.1212/WNL.0000000000004633}

\section{This information is current as of November 6, 2017}

\section{Updated Information \& Services}

Supplementary Material

\section{References}

Subspecialty Collections

Permissions \& Licensing

Reprints including high resolution figures, can be found at: http://n.neurology.org/content/89/19/2021.full

Supplementary material can be found at: http://n.neurology.org/content/suppl/2017/11/06/WNL.0000000000004 633.DC1

This article cites 1 articles, 1 of which you can access for free at: http://n.neurology.org/content/89/19/2021.full\#ref-list-1

This article, along with others on similar topics, appears in the following collection(s):

Clinical neurology examination

http://n.neurology.org/cgi/collection/clinical_neurology_examination Meningitis

http://n.neurology.org/cgi/collection/meningitis

Ocular motility

http://n.neurology.org/cgi/collection/ocular_motility

Information about reproducing this article in parts (figures,tables) or in its entirety can be found online at:

http://www.neurology.org/about/about_the_journal\#permissions

Information about ordering reprints can be found online:

http://n.neurology.org/subscribers/advertise

Neurology ${ }^{\circledR}$ is the official journal of the American Academy of Neurology. Published continuously since 1951, it is now a weekly with 48 issues per year. Copyright @ 2017 American Academy of Neurology. All rights reserved. Print ISSN: 0028-3878. Online ISSN: 1526-632X.

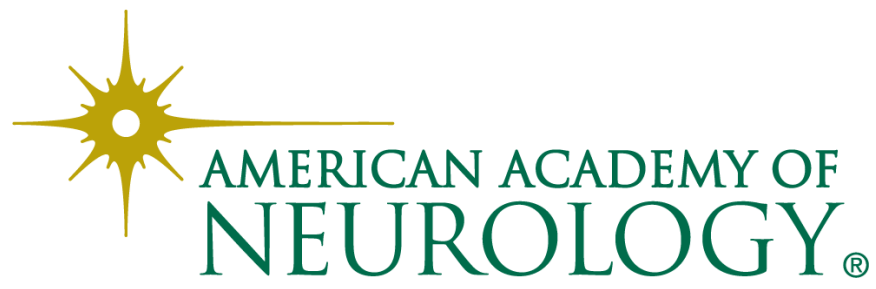

